\title{
WOMEN ATTRIBUTE AND HOUSEHOLD LEVEL FACTOR ON WOMEN'S EMPOWERMENT
}

\author{
Neneng Miskiyah \\ Department of Business Administration, Polytechnic of Sriwijaya, Palembang \\ Email: miskiyahneneng@gmail.com (corresponding author) \\ Sari Lestari Z Ridho \\ Department of Business Administration, Polytechnic of Sriwijaya, Palembang \\ Email: sarilestari@polsri.ac.id \\ Hadi Jauhari \\ Department of Business Administration, Polytechnic of Sriwijaya, Palembang \\ Email: hadievada@yahoo.com \\ Keti Purnamasari \\ Department of Business Administration, Polytechnic of Sriwijaya, Palembang \\ Email: keti.purnamasari@polsri.ac.id
}

Received: April 2021; Accepted: May 2021; Available online: July 2021

\begin{abstract}
Empowerment is an important strategy in increasing the role and opportunities of women in improving their economy and is an effort to increase and actualize their potential so that they are more able to be independent and work, and are more appreciated. This study aims to analyze the probability of empowering women in the songket craft business, testing and analyzing the variable women attribute and household level factor on women's empowerment. The population in this study were female songket craftsmen with a total sample of 100 respondents. The sampling technique used in this study was the snowball sampling technique. Tests are carried out using binary logistic regression. The results showed that the variables of age, education, and work experience had a significant effect on women's empowerment.The policy implication of the results of this study is that there needs to be more serious attention and involvement from the government and other institutions in coaching women songket craftsmen, and improving the quality of women through various activities to empower them through songket business activities.
\end{abstract}

Keywords: Women's Empowerment; Women Attribute; Household Level Factor; Gender.

\begin{abstract}
Abstrak
Pemberdayaan menjadi strategi penting dalam peningkatan peran dan peluang perempuan dalam meningkatkan ekonominya serta merupakan upaya peningkatan dan pengaktualisasian potensi diri mereka agar lebih mampu mandiri dan berkarya, serta lebih dihargai. Penelitian ini bertujuan untuk menganalisis probabilitas pemberdayaan perempuan pada usaha kerajinan songket, menguji dan menganalisis variable women attribute dan household level factor terhadap pemberdayaan perempuan. Populasi dalam penelitian ini adalah wanita pengrajin songket dengan jumah sampel sebanyak 100 responden. Teknik pengambilan sampel yang digunakan dalam penelitian ini adalah teknik snowball sampling. Pengujian dilakukan dengan menggunakan regresi logistik binary. Hasil penelitian diperoleh bahwa variable umur, pendidikan, dan pengalaman kerja yang memberikan pengaruh signifikan terhadap pemberdayaan perempuan.Implikasi kebijakan dari hasil penelitian ini adalah perlu adanya perhatian dan keterlibatan yang lebih serius dari pemerintah dan lembaga lainnya
\end{abstract}


dalam pembinaan perempuan pengrajin songket, serta peningkatan kualitas perempuan melalui berbagai kegiatan pemberdayaan melalui kegiatan usaha kain songket.

Kata Kunci: Pemberdayaan Perempuan; Women Attribute; Household Level Factor; Gender.

How to Cite: How to Cite: Miskiyah, N., Ridho, S. L. Z., Jauhari, H., \& Purnamasari, K. (2021). Women Attribute and Household Level Factor on Women's Empowerment. Media Ekonomi dan Manajemen, 36(2), 181-195. doi: http://dx.doi.org/ 10.24856/mem.v36i2.2124.

\section{INTRODUCTION}

The total female population is almost equal to the total male population, based on 2019 Indonesian statistics, the total male population is $50.24 \%$ $(133,136.1$ people), while the female population is $49.76 \%$ or $131,879.2$ people (BPS, 2019). This condition shows the enormous potential of women should be able to be empowered to be able to make a positive contribution in development. Women have great potential to play a role in the social, economic, political, educational and other fields. The role that is carried out certainly does not rule out the main role of women in managing their families coupled with an increase in women's participation in sustainable social development (Hasin et al., 2018).

Women have a role to be able to help support the economic needs of the family, so that empowerment in the economy such as entrepreneurship can be a means of increasing women's capacity. According to Varghese (2011) empowerment is an active multi-dimensional process, enabling women to realize their potential and strength in all areas of life. Providing freedom for women in terms of easy access to law, health, improving education, and politics is also important in women's empowerment and gender equality (Bangun, 2020).

In Indonesia, the creative economy has a very strategic role in economic development and business development. Creative economy is an economic concept in the new economic era that intensifies information and creativity which makes human resources the main capital, which is expected to be able to turn low-value goods into high-value and marketable goods (Daulay, 2018). Likewise, the development of creative industries in Palembang continues to be spurred as the variety of products and business actors continues to increase, and songket cloth becomes a superior product.

Empowerment of women through songket handicraft business is intended to explore deeper the potential and abilities possessed by women in trying and understanding women in terms of independence and internal strength from within themselves. Most of the women who work in the songket handicraft business are only craftsmen/laborers, and even they are unpaid workers on the grounds of working in their own family businesses. The helplessness of women causes many women songket craftsmen who are unable to get out of their hardships to meet household needs. Expertise in weaving is women's capital to earn income but with limitations and the Covid-19 pandemic, it has made it more difficult for women to develop the songket weaving business. Many factors influence women in developing themselves, such as women's education, family size, age of woman, marital status, work experience, and gender of household head. Several studies have shown that education has an important role for women to be more empowered. The higher the level of education of women, the greater the chance for women to develop themselves and be more empowered (Sheikh et al., 2016; Gholipour et al., 2010; Habib et al., 2019). However, the conditions that occur in Sri Lanka are that education does not contribute to women's empowerment (Yogendrarajah \& Semasinghe, 2013). 
Women who are married are less empowered than unmarried women (Biswas \& Mukhopadhyay, 2018)(Menon et al., 2020), however, several studies have found married women have a negative and significant effect on women's empowerment (Sheikh et al., 2016). Work experience is one of the determining factors for women's empowerment. The longer the work experience, the more skilled women are in carrying out their jobs. The case that occurred in Urmia County, Iran, which was found by Forouzani \& Mohammadzadeh (2018), turns out that work experience has an effect on women's empowerment. However, in contrast to the findings of Yogendrarajah \& Semasinghe (2013), work experience has no effect on women's empowerment in Sri Lanka.

In relation to the age of women, this factor can influence the way a person thinks and acts, especially in decision making. Age also affects women's productivity at work. According to BPS (2019) the productive age between 15 - 65 years is the ideal age for workers. Batool et al. (2017) state that women's age has a positive and significant effect on women's empowerment. Meanwhile, the results of the study by Haque et al.(2011) state that the older women are, the less empowered they are.

Sheikh et al. (2016) explain that women who are more empowered tend to have a smaller family size, especially when they are educated. The results of the study found a negative and significant effect of family size on women's empowerment, where the larger the family size, the more helpless the woman is because the less likely she is to take part in the decisionmaking process.Meanwhile Upadhyay and Karasek (2012) found that the bigger the family size, the more empowered women in Mali are, because they have the opportunity to develop themselves and make ends meet.

Women's empowerment is also influenced by the gender of household head, where women in households headed by men find it difficult to be more empowered (Ayevbuomwan et al., 2016), but if households are headed by women, women's empowerment will increase (Obayelu \& Chime, 2020).

There are many songket handicraft businesses in Palembang, and can be used as a business that can be done by women. Through this songket business, it provides opportunities for women to improve family welfare, but there are also many obstacles that women must face in running and developing the songket business.

This study focuses on factors that can influence women's empowerment grouped on woman attribute, namely age, education, marital status and work experience, and household level factors, namely family size and gender of household head. Different from previous studies, this study analyzes the probability and variables that affect women's empowerment which are categorized into two groups, namely (1) working on their own business; and (2) working in other people's businesses.

\section{LITERATURE REVIEW Women Empowerment}

The empowerment of women is a process in which women describe and recreate what they could do and in the laurels they previously could not afford.

This empowerment can include actions to improve the status of women through education, increase awareness, literacy, and training. Women are able to increase self-confidence to play a role and participate actively in making decisions through various problems in society (Rani \& Principal, 2019; Hunt \& Samman, 2016). The existence of a gender gap causes the condition of the inability of women to access work and the inability to maintain a job, even though women actually have the same rights as men in obtaining decent work in accordance with 
their abilities and qualities (Sulistyowati, 2015; Hasin et al., 2018).

\section{Determinants of Women's Empower- ment \\ The Effect of Women Attribute on Women's Empowerment}

Mahmud et al.(2012), Sheikh et al. (2016), and Trommlerová et al. (2015) analyze the effect of marital status on women's empowerment. The results of the study found that marital status had a significant effect. Married women have the opportunity to make decisions to develop themselves. Another finding obtained by Biswas \& Mukhopadhyay (2018) is that more than 50 percent of women have a low level of empowerment, 41 percent have moderate empowerment and only 7 percent reach a high level. In India, the marital status of a married woman actually prevents her from being more empowered. The low level of women's empowerment is also caused by the regulation of men or an older person to become the head of the family. Meanwhile, unmarried women have more freedom to increase their empowerment as a woman. This is in line with the results of research by Menon et al.(2020) which shows that married women are less empowered than unmarried women. Unmarried women living with their parents or living alone have the freedom to make decisions about themselves and their jobs, while for married women in India, these decisions are mostly made by their spouses and inlaws.

In terms of age, several studies reveal that age affects women's empowerment. The results of research presented by Batool and Jadoon (2018) reveal that empowerment increases with increasing age of women in the 41-49 year age group. This finding is also supported by the results of research by Khan and Awan (2011) which found a very significant relationship for each age category on women's empowerment. All age categories are significant above the reference category, namely ages 15-19 years. Women in the 40-44 year age group showed the highest chance of making economic decisions 2.82 times compared to those in the reference age category. Batool et al. (2017) and Sheikh et al.(2016) state that women's age has a positive and significant effect on women's empowerment. The older you get, the better your understanding of a job will be, and you will get richer work experience. In contrast to the findings of Haque et al.(2011), women with an older age than their husbands are less empowered in making economic decisions and making decisions in the household.

As women get older, the work experience for women gets better. Sohail (2014) found that women who have work experience and are given more training are able to increase women's empowerment. Women are given the same opportunity to acquire creative economic skills so that women can show their potential by engaging in creative activities such as crafts or arts. The goal is that women are not dependent on men. Work experience that is equipped with skills as a form of empowering women and giving them opportunities to develop. However, unlike the findings of Yogendrarajah and Semasinghe (2013), work experience has no effect on women's empowerment in Sri Lanka.

Sudatta et al. (2020) found that rural women in India who work, have their own source of income, with a higher level of education, are thus more empowered. The empirical findings of Bushra and Wajiha (2015), and Hazarika and Goswami (2016) found that education has a positive and significant effect on women's empowerment. The higher the level of women's education, the more empowered it means that education provides an important role for women's empowerment. However, in contrast to the research results of Swain and Wallentin (2008), and and Duflo (2011), education does not have an effect on women's empowerment. 


\section{The Effect of Household Level Factor on Women's Empowerment}

Research conducted by Sheikh et al.(2016) found that increasing the number of family members makes it increasingly difficult for women in Pakistan to enter the labor market, because they have to take care of the household. It was explained that family size has a negative effect on women's empowerment because the more children, the more busy women are, which causes less time for women to practice their empowerment. Increasing family size decreases empowerment by $10 \%$. In contrast to the cases that occurred in Namibia and Zambia, Upadhyay \& Karasek(2012) found that the smaller the number of family members, the women have the opportunity to empower themselves better. Meanwhile in Mali it is the opposite, the more the number of family members, the more empowered women in Mali.

Women's empowerment is also influenced by the gender of household head. Based on the results of research by Sheikh et al. (2016), explain that there is a negative and significant effect if the head of the family is male on female empowerment. This illustrates that in society there is full authority for men to make household decisions autocratically without the involvement of women in the home. The condition of women in Nigeria as stated by Obayelu \& Chime (2020) if they become the head of the household, women's empowerment will increase. Most decisions are made by the female partner, while the decision on how to spend her income is made jointly with the partner. The percentage of rural women who are helpless is greater than that of men. The results of this study are in line with the findings of Rani \& Principal (2019), that women have the same access and rights as men in controlling their own lives, both inside and outside the home.

The hypothesis is a temporary answer to a problem that is still presumptive, and the truth will be proven after the empirical data is obtained. In this study, the hypothesis proposed is as follows:

$\mathrm{H} 1$ : The probability of women working in their own business is greater than working in other people's businesses.

$\mathrm{H} 2$ : The older the woman, the greater the probability that women are more empowered to work in their own business compared to working in other people's businesses.

H3: The higher the level of education, the greater the probability that women are more empowered to work in their own business compared to working in other people's businesses.

H4: Women who have been married have a greater probability of being empowered to work in their own business than working in other people's businesses.

H5: Women with longer work experience are more empowered, and the less likely women are to work in their own business compared to working in other people's businesses.

H6: The bigger the family size, the greater the probability that women are more empowered to work in their own business compared to working in other people's businesses.

H7: Women as household heads are more empowered, and the greater the probability of working in their own business compared to working in other people's businesses.

\section{RESEARCH METHODS}

This type of research is quantitative research. This study is intended to determine how much the contribution of the independent variable to the dependent variable and the direction the relationship occurs (Sugiyono, 2014). The research location is in the Ki Gede Ing Suro area as one of the songket craft centers in Palembang. The population in this study were female songket craftsmen who entered the working age of 15 - 65 years (BPS, 2019). Determination of sample size 
using the Wibisono formula (Riduwan \& Akdon, 2013). The number of samples obtained were 100 respondents. The sampling technique used in this study was the snowball sampling technique where the sample was obtained through a rolling process from one respondent to another (Sekaran, 2011). This sampling process runs until a total sample of 100 respondents is fulfilled.

Empowerment of women as the dependent variable consists of 2 categories, namely (1) working in their own business, and (2) working in other people's businesses. The independent variables are (1) women attribute consisting of variables of age, education, work experience, and marital status, while (2) household level factor consists of family size and gender of household head.

If the dependent variable is qualitative data with a nominal scale and consists of 2 categories, then a binary logistic regression model is used (Hosmer, David W et al., 2013).

The logit model equation in this study is:

$$
\begin{aligned}
W E= & \ln \left(\frac{P}{1-P}\right)=\beta_{0}+\beta_{1} A G E+\beta_{2} E D U C+ \\
& \beta_{3} M A R+\beta_{4} W O R K+\beta_{5} F A M+ \\
& \beta_{6} G E N D+\varepsilon \ldots \ldots \ldots \ldots \ldots \ldots \ldots \ldots \ldots \ldots \ldots \ldots \ldots \ldots \ldots \ldots
\end{aligned}
$$

where:

$\mathrm{WE}=$ Women's empowerment

$$
\begin{aligned}
& (1=\text { working in their own } \\
& \text { business; } 0=\text { working in other } \\
& \text { people's businesses })
\end{aligned}
$$

$\mathrm{AGE}=$ Age

EDUC $=$ Education

MAR = Marital Status

WORK $=$ Work experience

FAM $=$ Family size

GEND $=$ Gender of household head

$\varepsilon=$ error term
To find out how much the probability of women working in their own business and working in someone else's business, an estimate of the probability is made for categories (1) working in their own business, and (2) working in other people's businesses.

$\operatorname{Pr}(Y=0 \mid X)=\frac{1}{1+e^{g 1(x)}} \ldots \ldots \ldots \ldots \ldots \ldots . .$.
$\operatorname{Pr}(Y=0 \mid X)=\frac{1}{1+e^{\left(\beta_{0}+\beta_{1} X_{1}+\beta_{2} X_{2}+\beta_{3} X_{3}+\beta_{4} X_{4}+\beta_{5} X_{5}+\beta_{6} X_{6}\right)}}$
$\operatorname{Pr}(Y=1 \mid X)=\frac{e^{g 1(x)}}{1+e^{g 1(x)}} \ldots \ldots \ldots \ldots \ldots \ldots \ldots . .$.
$\operatorname{Pr}(Y=1 \mid X)=\frac{e^{\left(\beta_{0}+\beta_{1} X_{1}+\beta_{2} X_{2}+\beta_{3} X_{3}+\beta_{4} X_{4}+\beta_{5} X_{5}+\beta_{6} X_{6}\right)}}{1+e^{\left(\beta_{0}+\beta_{1} X_{1}+\beta_{2} X_{2}+\beta_{3} X_{3}+\beta_{4} X_{4}+\beta_{5} X_{5}+\beta_{6}\right)}} \ldots$

\section{RESULT AND DISCUSSION \\ Respondent's Characteristics \\ Respondent Age}

In this study, it was determined that the respondents were women aged 15 years and over to 65 years who worked as songket craftsmen, both those who worked in their own businesses, as well as in other people's businesses. The results showed that the age of the respondents ranged from 19 years to 65 years. Most women who work in their own business are between the ages of 36 and 45 as many as 11 respondents (42.31 percent). Likewise, those who work in other people's businesses, the largest number are between the ages of 36 and 45 , which is 40.54 percent or 30 respondents.

From Figure 1 shows that the older the age, the smaller the chance of the respondent to work as a songket craftsman. In general, the average age of the respondents is at the level of the productive age group, where physically the respondents have a greater possibility to continue working as songket craftsmen to earn income to meet family needs. 


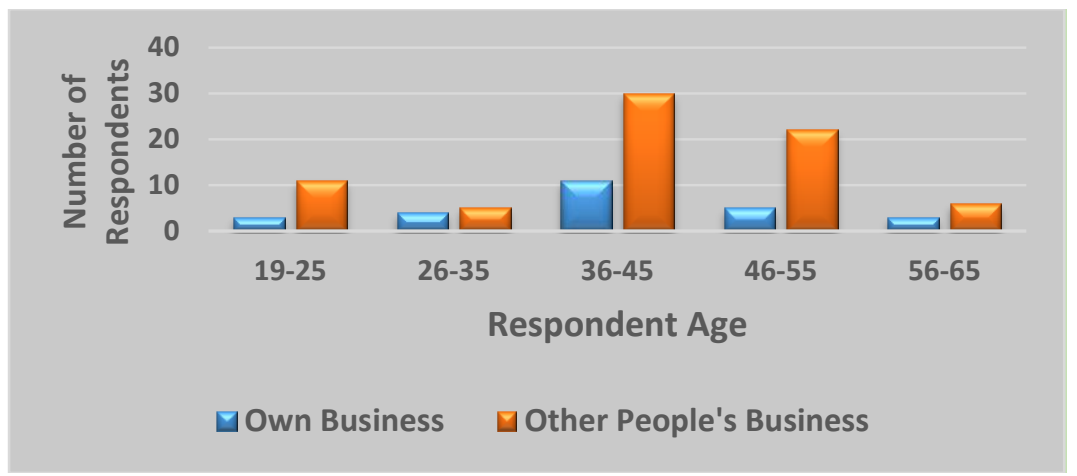

Figure 1. Chart of Female Workers by Age Group

Source: Results of data processing, 2020

\section{Respondents Education Level}

The education level of female songket craftsmen is the level of education that is completed formally, starting from elementary school (SD) graduates to final education as an undergraduate. However, out of the 100 respondents, 82 or 82 percent had the latest education at the Senior High School (SMA) level. If it is differentiated based on the women's empowerment group, namely those who work in their own businesses, and work in other people's businesses, then based on the results of the field survey for those who work in their own businesses, most are high school graduates/SMA (61.54 percent), 23.08 percent in education Diploma 3 and Bachelor degree by 19.23 percent, and 1 respondent who graduated from elementary school. Furthermore, for the group of women who work in other people's businesses, the level of education completed by the most respondents was at the high school level of 89.19 percent, followed by the Diploma 3 education level as many as 6 respondents (8.11 percent) and women with junior high school education level of 6.76 percent (5 respondents).

Education is seen as an investment whose rewards can be obtained several years later in the form of increased work results. When it is related to the level of education, out of 100 respondents, the number of respondents who work in their own business or work in other people's businesses is more dominated by those whose education level is at the SMA level. The following Figure 2 shows the distribution of respondents according to the level of education completed formally.

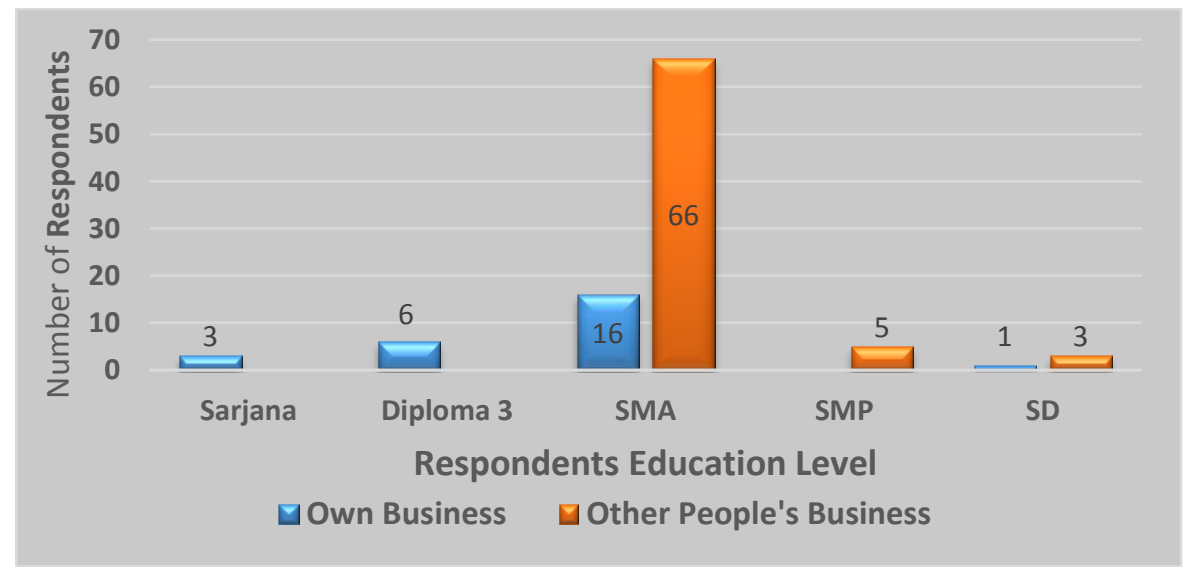

Figure 2. Chart of Female Workers by Education Level Source: Results of data processing, 2020 


\section{Respondents' Marital Status}

In this study, the respondents' marital status was grouped into 3 categories, namely married, unmarried, and widowed. The following Figure 3 shows the distribution of the distribution of the marital status of women songket craftsmen.

Figure 3 shows that out of 100 respondents, 67 percent of women are currently married. In the group of women who worked in other people's businesses, the number of women who were not married was 19 respondents greater than the group of women who worked in their own business, only 3 respondents. Meanwhile, the number of women who are widows among those who work in their own businesses and work in other people's businesses is almost the same.

\section{Respondents' Work Experience}

Work experience is the length of time that women work in the songket weaving business that is currently being undertaken. Work experience can affect the level of income, professional skills or expertise. The longer you pursue the songket weaving business, the more knowledge about consumer tastes will increase. Based on the data obtained, the work experience of women as songket craftsmen is mostly in the 13 to 24 year old group, both women who work in their own businesses by 42.31 percent, or work in other people's businesses by 35.14 percent. The following Figure 4 describes the work experience of women songket craftsmen.

From the field survey, data was obtained that women who run the songket weaving business are no longer for elderly women. Hereditary skills as songket craftsmen have been passed on to the younger generations, this is the case that quite a lot of young women aged between 19 and 25 (shown in Figure 1) have been engaged in songket weaving handicrafts.

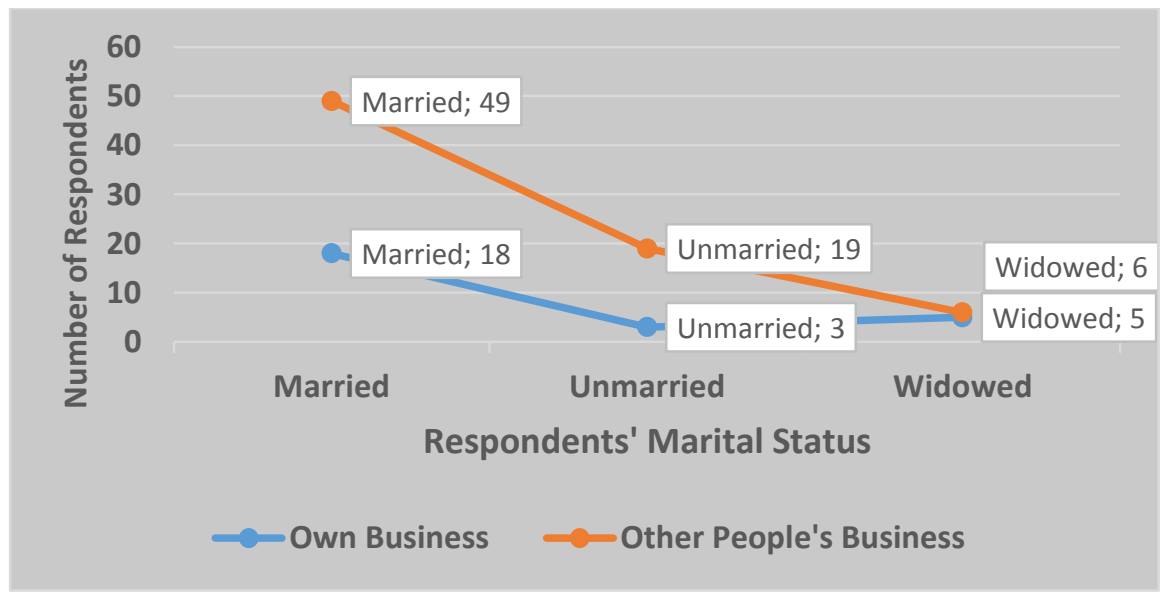

Figure 3. Chart of Female Workers by Marital Status

Source: Results of data processing, 2020

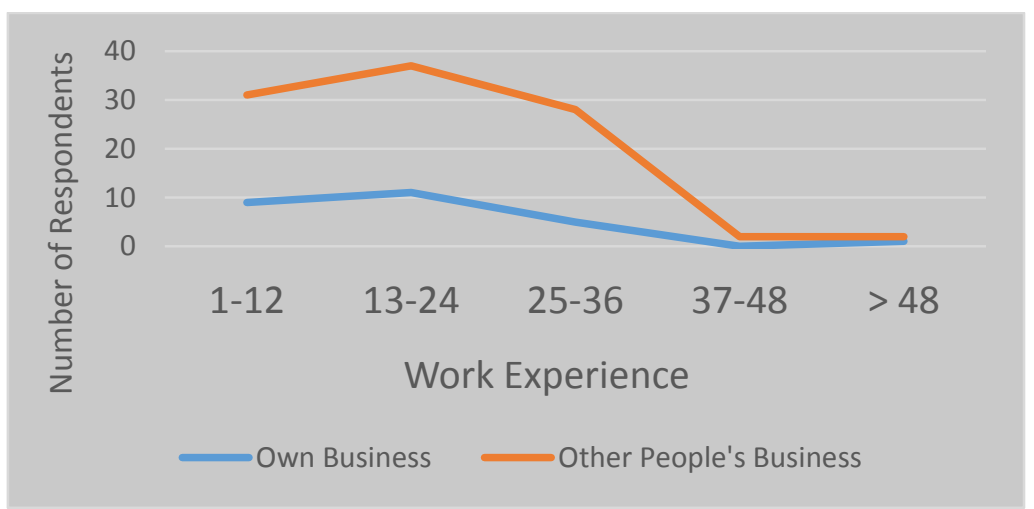

Figure 4. Chart of Female Workers by Work Experience Source: Results of data processing, 2020 


\section{Respondents' Family Size}

The characteristics of the next respondent are regarding the family size of the respondent. Based on the results of the field survey, it was found that the family size of the respondents averaged between 4 and 7 people. The percentage of the two groups of women working in their own business and working in other people's businesses to the number of respondents was 64 percent. Next, the family size between 1 and 3 people is 31 percent. The family size of the group of women who work in their own business is not more than 6 people, but the group of women working in other people's businesses is 5 percent between 7 and 9 people.

Figure 5 shows the same pattern in family size between women who work in their own businesses and work in other people's businesses, mostly between 4 to 6 people.

\section{Respondents's Gender of Household Head}

One of the household members who is responsible for fulfilling daily needs in the household or someone who is elder / considered / appointed as the head of the household (PEKKA \& SMERU, 2014). The still strong patriarchal culture in society causes a general tendency that the head of the household is male. In community life, there are many women as the head of the household. Based on the results of the field survey, there were 22 women who became the head of the family. There were 14 women working in their own businesses and 8 other people working in other people's businesses. Figure 6 shows that out of 100 respondents, only 22 percent of women act as family heads, and 78 percent are men as family heads.

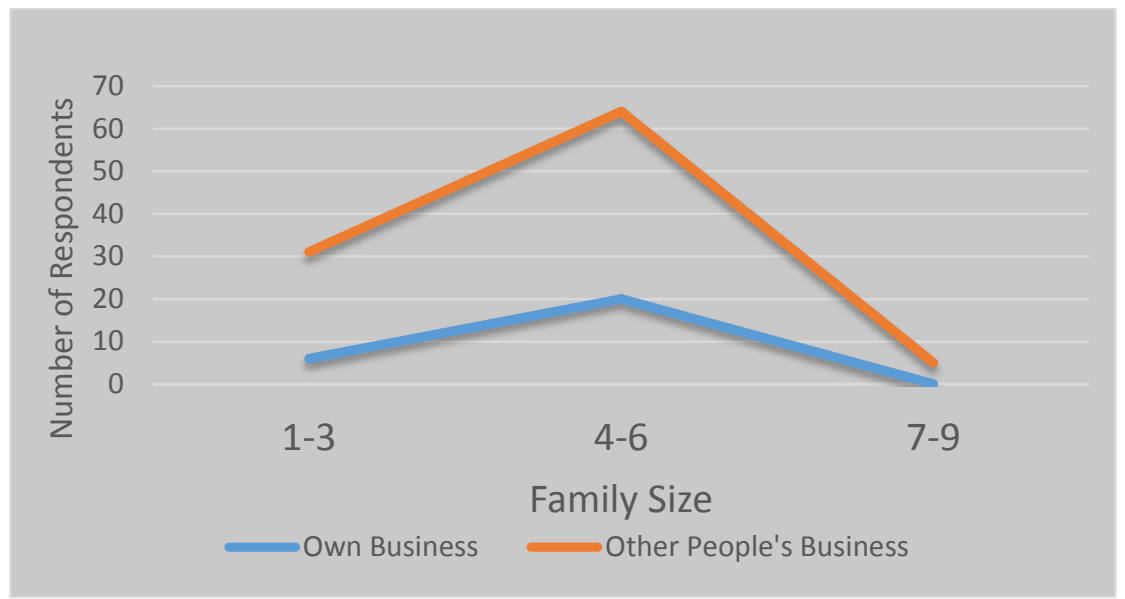

Figure 5. Chart of Female Workers by Family Size

Source: Results of data processing, 2020

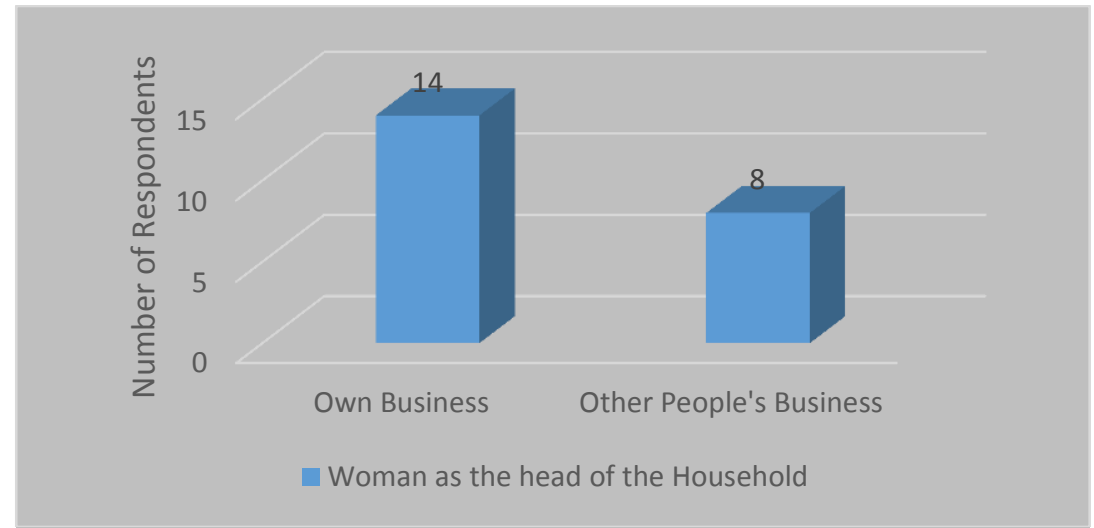

Figure 6. Charat of Female Workers as Head of Family

Source: Results of data processing, 2020 


\section{Inference Statistical Analysis of Variables Affecting Women's Empower- ment}

Empowerment of women is caused by many factors, both internal and external factors. Efforts to determine the factors that influence empowerment, then in this study, the dependent variable (Y) is women's empowerment, where the twocategory nominal scale dependent variable must be coded using 0 and 1 (Hosmer, David W et al., 2013)(Agresti, 2007). The dependent variable consisting of 2 categories is coded, namely $\mathrm{Y}=1$ working on one's own business, and $\mathrm{Y}=0$ working on someone else's business. Women's empowerment is influenced by the variable woman attribute, namely age (AGE), education (EDUC), marital status (MAR), work experience (WORK) and household level factor consisting of family size (FAM), and gender of household head (GEND).

Testing together to determine the effect of the independent variable on the dependent variable using the Omnibus Test and the results of data processing obtained a significance value of 0.000 , so that Ho decision was rejected because the significance value was smaller than $\alpha$ of 0.05 .

From Table 1, it is obtained the Chisquare value of 24,799 and a significance value of 0,000 . The value of the Chisquare table with a df of 6 , then the value of the Chi-square table is 11.243 or a significance value of $\leq 0,05$. From these results it is stated that the joint test of the independent variable has an effect on women's empowerment .

Partial testing is done to determine the significance of the independent variable parameters using the Wald test. The following test results are shown in Table 2. Based on Table 2, it explains that the significant parameter is the e $n$ coefficient of variables age, education, and work experience, because these two variables have a significance value $<0.05$, and one variable has a significance value $<0.10$. This explained that at the $5 \%$ and $10 \%$ significance levels, the education variable, work experience variable, and age variable had a significant effect on women's empowerment.

Table 1. Omnibus Test

\begin{tabular}{llccr}
\hline & & Chi-square & df & Sig. \\
\hline Step 1 & Step & 24,799 & 6 & .000 \\
& Block & 24,799 & 6 & .000 \\
& Model & 24,799 & 6 & .000 \\
\hline
\end{tabular}

Source: Results of data processing

Table 2. Partial Test Results for Independent Variables

\begin{tabular}{lrrrr}
\hline \multicolumn{1}{c}{ Independent Variable } & \multicolumn{1}{c}{ B } & \multicolumn{1}{c}{ Wald } & \multicolumn{1}{c}{ Sig. } & Exp (B) \\
\hline AGE & 0.113 & 3,371 & $\mathbf{0 . 0 6 6} *$ & 1,120 \\
EDUC & 0.895 & 10,832 & $\mathbf{0 . 0 0 1} * *$ & 2.448 \\
MAR & 1.074 & 1,396 & 0.237 & 2.928 \\
WORK & -0.135 & 5,592 & $\mathbf{0 . 0 1 8} * *$ & 0.874 \\
FAM & -0.020 & 0.009 & 0.925 & 0.980 \\
GEND & -0.858 & 0.573 & 0.449 & 0.424 \\
Constant & 14.216 & 9.888 & 0.002 & 0.000
\end{tabular}

Source: Results of data processing

* Significance at $\alpha=10 \%$

** Significance at $\alpha=5 \%$ 


\section{Estimation of Probability of Women's Empowerment}

To determine the probability of women's empowerment, a probability estimate is made for category (1) working on their own business; and (2) working in other people's businesses.

\section{Estimated Probability of Empowering Women Working in Own Business.}

By using formula (4) and (5), the results of the probability of women being more empowered in the songket weaving handicraft business who work in their own business are 0.782 times compared to women who work in other people's businesses.

\section{Estimation of the Probability of Empowering Women Working in Other's Businesses}

By using formula (2) and (3), the results show that the probability of women being more empowered in the songket weaving business working in other people's businesses is 0.218 times compared to women who work in their own business.

From Table 2 the partial test results show that the age variable has a significant effect on women's empowerment with a value of 0.066 . Values exp (B) or odds ratios, which are interpreted as risk or tendency empowerment of women based on variables that influence. Odd ratio value of the variable age of 1.120 , the value is clear that increasing age then the less chance the respondent to work on the efforts of others that have a tendency to work on the business alone amounted to 1.120 times more than working on the business of others. In general, the average age of the respondents is at the level of the productive age group.

Figure 1 shows that the most women working as songket craftsmen are those between the ages of 36 to 45 years, both those who work in their own businesses by 42.31 percent and work in other people's businesses by 40.54 percent. This result is in line with research conducted by Khan \& Awan (2011) which revealed that women's empowerment increases with age in the 4149 year age group. The age of female songket craftsmen who are between 36 years and 45 years is the productive age group, where at this age they have gained a lot of experience and good understanding in weaving songket. In this condition, it usually affects the processing time faster than those who are young between 19 - 35 years and 56 - 65 years. The increasing age of women who work as songket craftsmen has a strong enough influence on the decision to work on their own business or work in someone else's business. Batool \& Jadoon (2018), Sheikh et al., (2016), and Batool et al., (2017) found the same thing where women's age had a positive and significant effect on women's empowerment. However, in contrast to the findings of Haque et al. (2011), it is concluded that women's age does not have an influence on women's empowerment, especially in economic decision making and household decision-making.

The next variable that has a significant effect is the education variable. The odds of education is at 2.448 . This value explains that respondents who have a high level of education tend to work in their own business by 2.448 times more than respondents who work in other people's businesses. Education as an investment whose rewards can be obtained several years later in the form of increased work results. The higher the education, the higher the level of productivity. Songket craftsmen who have higher education have broad insights, and a more advanced way of thinking by utilizing technological advances. His entrepreneurial spirit appears along with the increase in knowledge when he follows formal education, so the opportunity to open his own business is greater.

Women have a very strategic role and function in the family and society, if women have extensive knowledge and a high level of education, then the role of 
women in the family will be high, even women's social roles in society are also high. Therefore education is one of the factors that enables women to have strong independence, especially independence in the family economy. Through this independence, women can be more empowered in both the family and society. The results of this study support the findings of Bushra and Wajiha (2015), Habib et al., (2019), and Hazarika and Goswami (2016) that the higher the level of education of women, the greater the chance for women to be more empowered. However, there are some studies that do not match this research. The results of research by Swain and Wallentin (2008) found that education had no effect on women's empowerment. This is due to policies and interventions from economic factors, changes in women's behavior and managerial control. If women's empowerment must be carried out by improving women's education, it requires greater participation and awareness creation from all members of the community. Yogendrarajah and Semasinghe (2013), and Duflo (2011) also found that education had no effect on women's empowerment.

The longer the work experience of women songket craftsmen will broaden their horizons and abilities in absorbing new things that can increase their knowledge and expertise in weaving songket. With the abilities possessed, these women can produce songket crafts that are increasingly numerous, varied, of quality and can quickly complete the tasks that are their responsibility. Variable work experience affect negatively and significantly, where odds values of work experience is exponential $(-0.135)$ for 0.874 . This value explains that respondents who have a longer work experience have a tendency to work in other people's businesses by 0.874 times less than working in their own business. Women with long work experience are usually retained by business owners by providing high rewards/wages in accordance with their expertise. The more work experience women songket craftsmen get, the more trained and skilled they will be in carrying out their work. The more work experience, the more empowered, where this condition greatly affects the production of songket. The findings of this study are in line with the findings of Welsh et al.(2016) and Sohail (2014) which state that women who have work experience and are given more training are more empowered. However, Yogendrarajah and Semasinghe (2013) actually found that work experience has no effect on women's empowerment in Sri Lanka.

\section{CONCLUSION AND RECOMMENDA- TION}

Based on the results of the analysis and discussion, the purpose of this study was to test whether the variable women attribute and household level factor had an influence on women's empowerment. The results were obtained simultaneously that all variables had an effect on women's empowerment, but based on partial testing, only age, education, and work experience variables had a significant effect on women's empowerment. This conclusion indicates that the results of the study support previous research which states that there is a positive and negative significant relationship between the variable women attribute and household level factor on women's empowerment. The stimulation of the probability of empowering women prefers to work in their own business. The policy implication of the results of this study is that there needs to be more serious attention and involvement from the government and other institutions in coaching women songket craftsmen, and improving the quality of women through various activities to empower them through songket business activities.

In this study there are still several limitations. First, the limitation of the research area which only focuses on one songket craft center.Second, the model in 
this study has not analyzed the effect of the variable of business length and husband's income as household level factors. Third, it has not analyzed the contribution of women to family welfare. Furthermore, the researcher can develop this research by expanding the research area, and including the variable length of business and variable of husband's income as independent variables, as well as analyzing family welfare as the impact of women's empowerment.

\section{REFERENCES}

Agresti, A. (2007). An Introduction to Categorical Data Analysis (Second Edi). John Wiley \& Sons, Inc. https://doi.org/10.1198/jasa.2008.s251 Ayevbuomwan, O. S., Popoola, O. A., \& Adeoti, A. I. (2016). Analysis of Women Empowerment in Rural Nigeria: A Multidimensional Approach. Global Journal of HumanSocial Science: C Sociology \& Culture, 16(6), 19-32.

Bangun, B. H. (2020). Hak Perempuan dan Kesetaraan Gender dalam Perspektif Filsafat Hukum. Pandecta Research Law Journal, 15(1), 74-82. https://doi.org/10.15294/pandecta.v15 i1.23895

Batool, S. A., Ahmed, H. K., \& Qureshi, S. N. (2017). Impact of Demographic Variables on Women's Economic Empowerment: An Ordered Probit Model. Journal of Women and Aging, 30(1), 1-22.

https://doi.org/10.1080/08952841.201 6.1256734

Batool, S. A., \& Jadoon, A. K. (2018). Women's Empowerment and Associated Age-Related Factors. Pakistan Journal of Social and Clinical Psychology, 16(2), 52-56.
Biswas, C. S., \& Mukhopadhyay, I. (2018). Marital Status and Women Empowerment in India. Sociology International Journal, 2(1), 29-37. https://doi.org/10.15406/sij.2018.02.0 0030

BPS. (2019). Sakernas Februari 2019. BPS RI.

Bushra, A., \& Wajiha, N. (2015). Assessing the Socio-Economic Determinants of Women Empowerment in Pakistan. Procedia Social and Behavioral Sciences, 177(July 2014), 3-8. https://doi.org/10.1016/j.sbspro.2015. 02.321

Daulay, Z. A. A. (2018). Strategi Pengembangan Ekonomi Kreatif Dengan Metode Triple Helix (Studi pada UMKM Kreatif di Kota Medan). Tansiq, 1(2), 169-190.

Duflo, E. (2011). Women's Empowerment and Economic Development. Working Paper Series, 17702(July), 1-7.

Forouzani, M., \& Mohammadzadeh, L. (2018). Empowerment of the Members of Rural Women's Cooperatives: The Impact of ICTs in Rural Districts of Urmia County, Iran. Asian Women, 34(4), 77-99. https://doi.org/10.14431/aw.2018.12.3 4.4.77

Gholipour, A., Rahimian, A., Mirzamani, A., \& Zehtabi, M. (2010). Impacts Model of Women's Empowerment. International Business Research, 3(1), 57-65.

Habib, K., Shafiq, M., Afshan, G., \& Qamar, F. (2019). Impact of Education on Women Empowerment. European Online Journal of Natural and Social Sciences, 8(3), 62-74.

Haque, M., Islam, T. M., Tareque, I., \& Mostofa, G. (2011). Women Empowerment or Autonomy: A Comparative View in Bangladesh Context. Bangladesh E-Journal of Sociology, 8(2), 17-30. https://www.bangladeshsociology.net/ 8.2/2BEJS 8.2-3.pdf 
Hasin, F., Hasan, A. K. M. B., \& Musa, H. (2018). Women Empowerment Model: Strategies To Overcome Challenges. J Fundam Appl Sci, 10(1S), 1068-1083. https://doi.org/10.4314/jfas.v10i1s.78

Hazarika, B., \& Goswami, K. (2016). Do Home-Based Micro-Entrepreneurial Earnings Empower Rural Women? Evidence from the Handloom Sector in Assam. Asian Journal of Women's Studies, 22(3), 289-317. https://doi.org/10.1080/12259276.201 6.1205376

Hosmer, David W, J., Lemeshow, S., \& Sturdivant, R. X. (2013). Applied Logistic Regression. (Third Edit). John Wiley \& Sons, Inc.

Hunt, A., \& Samman, E. (2016). Womens Economic Empowerment. Navigating Enablers and Contraints. Research Report. (Issue September).

Khan, S. U., \& Awan, R. (2011). Contextual Assessment of Women Empowerment and Its Determinants: Evidence from Pakistan. In Munich Personal RePEc Archive (No. 30820). Mahmud, S., Shah, N. M., \& Becker, S. (2012). Measurement of Women's Empowerment in Rural Bangladesh. World Development, 40(3), 610-619. https://doi.org/10.1016/j.worlddev.20 11.08.003

Menon, S., Ranjitha, M., \& Sharma, S. (2020). A study on the Status of Women's Empowerment in Urban Bangalore, India. Journal of International Women's Studies, 21(5), 54-64.

Obayelu, O. A., \& Chime, A. C. (2020). Dimensions and Drivers of Women's Empowerment in Rural Nigeria. International Journal of Social Economics, 47(3), 315-333. https://doi.org/10.1108/IJSE-07-20190455
PEKKA, \& SMERU. (2014). Menguak Keberadaan dan Kehidupan Perempuan Kepala keluarga (PEKKA \& SMERU (ed.); Cetakan 1). Lembaga Penelitian SMERU.

Rani, K., \& Principal, M. (2019). Women Empowerment- A Tool of National development. Journal of Emerging Technologies and Innovative Research (JETIR), 6(3), 186-190.

Riduwan, \& Akdon. (2013). Rumus dan Data Dalam Analisis Statistika. Alfabeta.

Sekaran, U. (2011). Research Methods For Business: Metodologi Penelitian untuk Bisnis (Buku 2, Edisi 4). Salemba Empat.

Sheikh, Q. A., Meraj, M., \& Mahapara Sadaqat. (2016). Gender Equality and Socio-Economic Development Through Women's Empowerment in Pakistan. Ritsumeikan Journal of Asia Pacific Studies, 34(February), 142160.

https://www.google.com/search?q=Ge nder+equality+and+socioeconomic+development+through+wo men's+empowerment+in+Pakistan\&rl $\mathrm{z}=1 \mathrm{C} 1 \mathrm{EJFA}$ _enMY768MY768\&oq= Gender+equality+and+socioeconomic+development+through+wo men's+empowerment+in+Pakistan\&a qs $=$ chrome..69i57.597

Sohail, M. (2014). Women Empowerment and Economic Development-an Exploratory Study in Pakistan. Developing Country Studies, 4(9), 163-170.

Sudatta, B., Swati, A., \& Bincy, G. (2020). Determinants of Women Empowerment as Measured by Domestic Decision-Making: Perspective from a Developing Economy. Advanced Issues in the Economics of Emerging Markets, 27, 1-12. https://doi.org/10.1108/S1571038620200000027001

Sugiyono. (2014). Metode Penelitian Kuantitatif, Kualitatif dan $R \& D$. Alfabeta. 
Sulistyowati, T. (2015). Model

Pemberdayaan Perempuan dalam Meningkatkan Profesionalitas dan Daya Saing untuk Menghadapi Komersialisasi Dunia Kerja. Jurnal Perempuan Dan Anak, 1(1), 1-11. https://doi.org/10.22219/jpa.v1i1.274 8

Swain, R. B., \& Wallentin, F. Y. (2008). Economic or Non-Economic Factors - What Empowers Women? Working Paper Series, 11, 1-38.

http://ideas.repec.org/p/hhs/uunewp/2 008_011.html

Trommlerová, S. K., Klasen, S., \&

Leßmann, O. (2015). Determinants of Empowerment in a Capability-Based Poverty Approach: Evidence from the Gambia. World Development, 66, 115. https://doi.org/10.1016/j.worlddev.20 14.07.008

Upadhyay, U. D., \& Karasek, D. (2012). Women's Empowerment and Ideal Family Size: An Examination of DHS Empowerment Measures in SubSahara Africa. International Perspectives on Sexual and Reproductive Health, 38(2), 78-89. https://doi.org/10.1363/3807812

Varghese, T. (2011). Women Empowerment in Oman: A Study Based on Women Empowerment Index. Far East Journal of Psychology and Business, 2(2), 3753. https://www.researchgate.net/publicat ion/50829269

Welsh, D. H. B., Memili, E., \& Kaciak, E. (2016). An Empirical Analysis of the Impact of Family Moral Support on Turkish Women Entrepreneurs. Journal of Innovation \& Knowledge, $1,3-12$.
Yogendrarajah, R., \& Semasinghe, D. (2013). Impact of Demographic Factors on Women Empowerment Through Micro Credit - A Special Reference to Jaffna District. ZENITH International Journal of Business Economics \& Management Research, 3(10), 59-67. 